Драган Б. Бошковић

https://doi.org/10.18485/ai_zsjoski.2018.1.2

Универзитет у Крагујевцу

821.163.41-31.09 Андрић И.

Филолошко-уметнички факултет

Одсек за филологију

Катедра за српску књижевност

\title{
НИХИЛИСТИЧКИ УДЕС ЗНАКА У АНДРИЋЕВОЈ ПРОЗИ ${ }^{1}$
}

Нихилирањем конвенционалног хуманистичког читања, рад указује да у делу Иве Андрића преовладава танатофилни идентитет знака (гроб, хумка, мост, камен...), па тако његова уобичајено идеолошки центрирана семантика мора бити превреднована онтолошким идентитетом. Насупрот разумевања знака као естетске (језичке, наративне) или етнокултуролошке и геоисторијске идеологеме, понудићемо његово разумевање као непремостивости, као метакомуникативности, као онтолошке пукотине и семиолошког понора. Пукотина у знаку сагласна је пукотини у субјекту, пукотини у бићу, кроз коју се смрт/Друго објављује као извор означавања, нарације и културолошког идентитета.

Кључне речи: знак, мост, смрт, дискурс, пукотина, Друго

Понудићемо нихилистичко читање Андрића, и то пре свега у смислу нихилирања конвенционалних читања његовог дела, која га затварају у распоред пој-

* boskovicbdragan@gmail.com

1 Рад је део истраживања на пројекту 178018: Друштвене кризе и савремена српска књижевност и култура: национални, регионални, европски и глобални оквир Министарства просвете, науке и технолошког развоја Републике Србије. 
мова без дубине, и тако покушати Андрићеву знаковност да отворим „поразу” означавања у којем видим најдалекосежније домете његовог текста, једну пресудну слику хуманизма, један бескрајни трагизам. Нихилирањем, дакле, стереотипних хуманистичких читања, указаћемо да у Андрићевој прози преовладава танатофилни идентитет знака (мост, гроб, камен, прича...). Насупрот схватања знака као естетске (језичке, наративне) или етнокултуролошке и геоисторијске идеологеме, разумеваћу га као клизање у Друго, као метакомуникативност, као онтолошку пукотину и семиолошки понор. Деконструкционистичко читање, дакле, водиће нас онтолошкој напуклости знака. А пукотина у Андрићевом знаку сагласна је пукотини у субјекту, пукотини у бићу, кроз коју се смрт објављује као извор означавања, нарације, уметности, хуманизма.

Па да кренемо....

Шта је тај мост, дефинисан, одређен, естетски уобличен? Шта је то он који је тако нестрпљиво убачен у друштвене и историјске улоге? Као да превиђамо да у његовој идентификацији увек остаје нешто прећутано и скривено, што упорно прогони јунаке које повезује и раздваја? Мост је, постструктуралистички схваћен, увек оно Друго, никада свој и на истом месту; он је тек један себи измичући знак. Знак, тврди деконструкција, не може себе уписати без цепања које носи у себи, ако, дакле, собом не отвори пукотину или расцеп (в. Дерида 1988). С обзиром на то да је тај однос комплексан и динамичан, онда знак никада није једнозначан, хомоген или кохерентан, лишен напетости и парадокса. Трагично расцепљен између истог и различитог, себе и Другог у себи, себе и оног ништа Другости по чију цену се појављује асимилујући је у себе, знак је хетерогена структура, нејединствени „елемент” који плете мрежу у коју је сам ухваћен, 
континуирано одгађање, једно немогуће које нас изнова убацује у бескрајну игру означавања и симболичког узајамног идентификовања моста и гроба, знака и смрти, уметности и смртности.

Загонетност чињенице да везир Јусуф из приче „Мост на Жепи” брише понуђени натпис за мост, и да „Тако остаде мост без имена и знака”, води нас у тајну моста и везира. Зато се морамо вратити податку да се идеја моста рађа из искуства тамнице и искуства тада у везиру објављене смрти. „Живећи заточен, у осами и немилости” (Андрић 1991б: 165), он је тада осетио „бео гладак зид од тесана камена” (Андрић 19916: 167), који ће се материјализовати у самој грађевини на Жепи. Племенита идеја стварања моста тако се јавља као наличје „племенитости” смрти која се дарује у искуству тамнице, која му је „из ноћних снова, као неодређен ужас, прелазила у јаву, и тровала му дане”, па везир „омрзну седеф, јер га је у мислима везивао с неком студеном пустоши и осамом. Од додира седефа и од самог погледа на њ трнули су му зуби и пролазила језа уз кожу" (Андрић 1991б: 170). Тако је, тврди приповедач, „и не слутећи улазио у оно стање које је прва фаза умирања, кад човек почне да с више интереса посматра сенку коју ствари бацају него ствари саме” (Андрић 19916: 170-171) ), као што „људи и не слуте колико има моћних и великих који ћутке и невидљиво, а брзо, умиру у себи” (Андрић 1991б: 171), јер најделикатније су мисли „које нас гурају у старост пре времена и у праву смрт пре умирања" (Андрић 1991в: 19). У свету сенки и страха, камена тамнице и језе седефа, носталгије и визије, опет, почевши од онога ништа смрти које опседа и Андрићевог Гоју, рађа се мисао о естетици и уметности, као истовременог самоиспољења трага/ сенке/смрти утиснутих у тој мисли. 
Док га смрт тихо узима у загрљај, у везиру Јусуфу се утврђује идеја о грађењу моста, а мислећи на „странца неимара који је умро” (Андрић 19916: 171), „Однекуд се устали у њему ова мисао: свако људско дело и свака реч могу да донесу зло" (Андрић 19916: 170). Мртав пре физичке смрти, везир уписује уметнички знак (мост) у нашу стварност, али заједно са фикционим Гојом свестан да је уметност наличје смрти: „око лепоте су увек”, рећи ће Гоја, „или мрак људске судбине или сјај људске крви. Не треба заборавити да сваки корак води ка гробу" и „У простоти је клица будућности, а у лепоти и сјају непреварљив знак опадања и смрти” (Андрић 1976: 13). Са свешћу да уметност продужава зло, као и да су уметничка дела само надгробни споменици, везир на мост не утискује никакав знак и „Тако остаде мост без имена и знака" (Андрић 19916: 171), као што тако остаде и Ћамилов гроб „са белим каменом без натписа” (Андрић 1991а: 104), и фра Петров, „Само гроб међу невидљивим фратарским гробовима, изгубљен попут пахуљице у високом снегу што се шири као океан и све претвара у хладну пустињу без имена и знака" (Андрић 1991а: 17). Тако се све слива ка знаку одсуства јер човек је мртав пре него што је заиста мртав, а уметничка дела дарови су смрти, јер, онако како је то Гоја из Разговора са Гојом желео и поетички исповедао: „сва стварност што постоји једна је једина стварност" (Андрић 1976: 17). А у том јединственом онтолошком пејзажу, смрт и знак или камен и тамница јединствени су и нераскидиви, као што су то и надгробни споменик и мост. И зато, подређен логици смрти, њеној блискости мосту и обрнуто, „предео није могао да се приљуби уз мост, ни мост уз предео” (Андрић 19916: 171), или мост уз уметност и уметност уз мост. Као надгробна плоча, мост је већ знак, али неозначен натписом (тарихом) да не би наставио производњу зла, јер је већ довољно зао; као надгробни споменик без знака, 
он наставља самообјављивање и означавање смрти; као знак смрти, он производи и усмерава логику нестајања, јер као и мост, као и знак, и „Човек треба да нестане без трага" (Андрић 1991в: 13).

Ако је тако, свет је онда некрофилни пејзаж: гробље прича и уметничких дела. Ћамилов бели гроб без натписа, везиров мост без имена и знака, фра Петров завејани гроб, Мехмед-пашина ћуприја, само су белези смрти. Умревши и пре своје смрти, Ћамил није умро већ је остао оно што јесте - Џем султан. Зато је Ћамил осуђен да живи своје одсуство које не може да се укине ни његовом смрћу, јер оно неизмерно не припада њему и никако не може бити склоњено са сцене или пресељено у белину одсуства гроба. Зато и мост, као и смрт, не припадају никоме, осим оном удаљеном, непознатом, скривеном у смрти: фра Петар је мртав да би прича постојала; непредстављена смрт везира Јусуфа на крају приче није ни могла бити представљена будући да је он мртав пре смрти. Из рађања смрти у везиру настаје његов надгробни споменик, мост, а добро и лепо су његови велови, прихватљиви вишак, хумано стварање чија утварна структура гради закон немогућег. А када се оно немогуће учини могућим, деси се догађај, мост, али он је већ био присутан у оној, у себи скривеној смрти, а насилно именовање и означавање само наставља да обележава тај догађај смрти, попут трага могућег и дозивања немогућег, и раскрива и скрива, попут уметности, немогућност означавања и бескрајно нестајање без трага.

Читајући роман На Дрини ћуприја од краја можемо утврдити симболичке релације између Алихоџе и пукотине на мосту која - рећи ће Андрић у „Мостовима” да мост „пресечен по половини” - „допушта једну једину могућност: непостојање" (Андрић 1991г: 134). Непо- 
стојање чега? Ако знак заиста јесте премештање, фигура, онда у његовом стварању и обележавању оног Другог (црне пруге), мост је, као и човек, поновимо за Фукоом (в. Фуко 2007) или са Деридом, „пукотина у поретку ствари” (в. Дерида 1988), расцеп у логици означавања. Пукотина „између тамнозелених брда са три стране” (Андрић 1991д: 113), „црна пруга која с времена на време, за секунду-две пресече груди надвоје и заболи силно" (Андрић 1991д: 119), није искупљена када је Мехмед-паша Соколовић у себи „угледао чврсту и витку силуету великог каменог моста" (Андрић 1991д: 121). Дубоко одређујући идентитет моста, црна пруга ће морати да објави промашај означавања. Тарих, утиснут на мост, потврда је да мост, као знак у мрежи знакова, мора да траје, као што на крају романа, заједно са Алихоџиним срцем, мора да напукне. Уколико мост посредује између страна и кроз роман заплиће судбине људи и царстава, он их исто тако и раздваја. Ако је „век (моста), иако смртан по себи, личио на вечност јер му је крај био недогледан" (Андрић 1991д: 169), онда ће он само објављивати своју смртоносност и то кроз своју везу са људима; ако „Мехмед-паши није било суђено да живи без тог бола” (Џаџић 1991: 57), школски упрошћено је закључивати да „ако он [мост] постоји, црна пруга не постоји” (Џаџић 1991: 57), јер смрт, митолошки самообличена као црна пруга постоји баш и једино у структури моста и знака. С обзиром на то да су се поистоветили са мостом, Мехмед-пашу смрт стиже пре него мост означи црну пругу, а Алихоџу, чувара моста, „она бела, широка хартија швапског прогласа пресекла је по половини као безгласна експлозија и ту зјапи провалија” (Андрић 1991д: 225). Индикативно је самообјављивање пукотине у субјекту, мосту, свакоме ко је симболички везан за мост, чиме се, постструктуралистички, потврђује да је „провалија” у нама, у знаковима, и да је Андрићев свет - естетизовани свет мртвих, па 
није случајно што Алихоџа слуша шале на свој рачун са улице „мирно, јер за њега су ти људи покојници који се још нису смирили” (Андрић 1991д: 318). Задатак моста је изневерио њега самог јер он има сасвим други задатак, да, као сваки знак, као белег, иза симболичког и практичног идентитет објављује смрт, и да под иманентном силом дискурса наставља да расипа симболичко кодирање: „ево је и сама везирова ћуприја почела да се осипа као ђердан; а кад једном почне, нико га више не задржа" (Андрић 1991д: 439).

Неприпадајући никоме, ни Махмед-паши, ни Алихоџи, мост и смрт су власници свега, а свему што је себе означило мостом, мост је убица. На једној страни, дакле, остају мостови, речи, прича која продужава „илузију живота” (Андрић 1976: 70), „А то што се плодимо, то је само илузија, јер све што се дешава у границама је смрти на коју смо осуђени и због које смо на земљу бачени" (Андрић 1991в: 17), као што „народ памти и препричава оно што може да схвати и што успе да претвори у легенду. Све остало пролази мимо њега без дубљег трага" (Андрић 1991д: 120). Ако се вратимо Проклетој авлији видећемо такође да оно што је означено оставља онтолошки ожиљак смрти, па ће и Карађоз тврдити: „Ја људе знам, криви су сви” и „ко овде дође, тај је крив, или се макар очешао о кривца" (Андрић 1991а: 76). По неумитној логици, етички налог једнак је онтолошком: ко се „очешао о мост” смрт га је већ обузела; по истој логици за Ћамила је остало записано „Да је без порока” (Андрић 1991a: 64). Танатофилна кодираност моста у На Дрини ћуприја, опет, мимоилази оне јунаке који су померили сопствено значење у односу на стереотипну семантику моста, који се нису „очешали” о знак. Почевши са оном коју су „прозвали луда Илинка”, која је „остала да живи, као мирна луда, ту поред градње” (Андрић 1991д: 131), а чији идентитет као знака се губи настанком моста, јер 
оно друго у њој задржавало ју је толико близу и толико далеко од њега да је он није могао узети. Милан Гласинчанин, такође, остаје померен у односу на њега, а после сусрета са ђаволом прелазио је „мост тешким и спорим кораком месечара” (Андрић 1991д: 256), као и Ћоркан, који је „ходао онуда куда је забрањено и куда нико не иде" (Андрић 1991д: 310). Ако ход оградом моста обележава кретање оштрицом знака, исти гест ће поновити и Никола Пецикоза, „безумник”, „блесав младић и добричина”, који је прешао мост „као месечар” (Андрић 1991д: 373-374), након чега ће нестати из приче. И Ћоркан, и Ћамил, и Илинка налазе свој излаз у оном што лунатички надилази означено, а тако успевају да избегну и сопствену смрт. Исто he се догодити и Лотики, чији је прозор „гледао изблиза и право на први, најужи лук моста” (Андрић 1991д: 192). Иако и сама „мост” између светова, као и Илинка или Ћоркан, Лотика такође остаје ослобођена смрти у мосту, учвршћујући се у ужасу безумља, у другости лудила, егзистенцијално излечена и спасена од Алихоџине и Мехмед-пашине смрти у знаку.

\section{$* * *$}

Као сваки знак, као и сам субјект, он је „подељена суштина" (Лакан 1988: 224), која се објављује по мери сопствене расцепљености. Ходати по знаку, везивати светове, шетати каменом ћупријом, уметничком делу, могуће је по цену смрти, а са оне стране остаје нада да се у ништа смрти тек буде. Овако дубока веза моста и смрти, веза између светова који су већ сједињени и које тек идеолошки, а тако вештачки раздвајамо, испољава се у знаковима и мостовима као идентитету смрти, чиме се естетска и хуманистичка визија мостова у стваралаштву Иве Андрића драстично изврће. Нихилистичко читање објављује, дакле, поредак смрти као лице хуманости. И док је окупљао царство и царства, и док је зближавао, 
и меркантилно и геополитички осмишљавао семантику историје, мост је истовремено био надгробни споменик те историје. Зато смо се отворили невидљивим луковима међу немогућим световима у Андрићевој прози, утолико снажнијим уколико су више скривени. Досегнути њихов врх значи сурвати се у ништа, онако како ће, када буде прешла највишу тачку моста, Авдагина Фата већ у следећем трену, када мост нагло креће доле, скочити са њега.

Шта је тај мост, дефинисан, одређен, естетски обликован? - запитали смо се на почетку овог излагања. Само знак одсуства, јер, тврди Дерида, на знакове се може гледати само док они настављају да производе ефекте с оне стране сваке врсте присуства (в. Дерида, 2005: 17), па се тако на (не)обележени и (не)именовани мост онда може гледати само као на знак који историјски наставља да производи значења смрти као самооспољење оног неименованог у себи. И то одсуство се намеће као генеалогија идентитета. И зато, подизањем моста, губитак се уводи у свет. И, уколико „обележје брише разлике” (Лакан 1988: 225), а име метафору, необележеност „Моста на Жепи", Ћамиловог и фра Петровог гроба јесте необележеност која омогућава да метафора и разлика постоје. И зато Ћамил, Лотика, луда Илинка јесу они који су се већ окренули оним могућим мостовима који сједињују, оним одсутним у њима и присутним у Другом, и суочили нас са чињеницом да су они заправо једини мостови. Игра понављања Другости и Истости у Андрићевој фигурацији моста употребљена је, наиме, да би се доделио идентитет и обухватио његов губитак, као и да би се наративном симболизацијом дао глас ономе што свој језик нема. Мост без имена и знака; приповедање без гласа. А само такви знакови сведоче о историји, означавању, приповедању, идентитетима, нама самима, о громној и несагледивој празнини. А мостови, као и надгробни споменици не говоре ни о чему другом осим о томе да „Ничега нема. 
Само снег и проста чињеница да се умире и одлази под земљу" (Андрић 1991а: 121). Или, тачније, једино знакови, мостови и надгробни споменици сведоче о историји или идентитетима, који тек тада, из ништа смрти као њиховог исходишта, настављају да живе своје неупоредиво присуство и одсуство.

Из истог, „нихилирајућег” угла могли бисмо да отворимо и следећа питања:

1. 1. Знаковност Андрићеве Босне као онтолошки нецеловитог идентитета (в. Тодорова 2006: 68, 74, 523; Бошковић 2011a);

2. Поделеност братских односа, јер „све се сводило на једно: постоје два света, између којих нема и не може бити ни правог додира ни могућности споразума, два страшна света осуђена на вечити рат у хиљаду облика" (Андрић 1991а: 89);

3. Етнички расиепљени идентитети (Мустафа Маџар: „Иако му је дјед Авдага Маџар, чувени потурчењак из старе и угледне мађарске породице” (Андрић 1991в: 19); Ћамил: „Од оца Турчина и мајке Гркиње” (Андрић 1991а: 42); Џем султан: „а мајка је била од кнежевског рода из Србије." (Андрић 1991а: 67) (в. Бошковић 2011б);

4. Идентитет као Друго (Ћамил није Ћамил, Џем је);

5. Прича као маска, лаж, илузија (фра Петар постоји само као маска приче и има своју улогу (у цивилно је обучен) у „театру сенки” Проклете авлије; сви у Авлији причају, измишљају, лажу; „А та прича као да жели, попут причања легендарне Шехерезаде, да завара крвника, да завара неминовност трагичног удеса који нам прети, и продужи илузију живота и трајања" (Андрић 1976: 65-66) (в. Бошковић 2010);

6. Нестанак приче (неочекивано, писац аутопоетичког есеја „О причи и причању”, у Проклетој 
авлији бележи: „Нема више ни приче ни причања” (Андрић 1991а: 121), јер Ћамил је једина и зато неиспричана прича у роману;

7. Прича као глас Другог (јер прича је „изговорена не Ћамиловим него другим гласом" (Андрић 1991а: 92) (в. Бошковић 2010));

8. Андрићев нихилизам („Оно што није, што не може и не треба да буде било је јаче од оног што јесте и што постоји, очигледно, стварно и једино могуће.) (Андрић 1991а: 93);

9. ...

И тако у недоглед, у игру знакова, у хуманизам, у нихилизам, у семиолошке и наративне пукотине и елипсе, у људски трагизам... У Андрића.

\section{Литература}

Андрић 1976: Иво Андрић, Историја и легенда (есеји, огледи и члании). Сабрана дела, Сарајево, Загреб, Београд, Љубљана, Скопје, Титоград: Свјетлост, Младост, Просвета, Државна заложба Словеније, Мисла, Побједа.

Андрић 1991а: Иво Андрић, Проклета авлија. Сабрана дела, Београд: Просвета, БИГЗ, СКЗ, Нолит.

Андрић 19916: Иво Андрић, Жеђ. Сабрана дела, Београд: Просвета, БИГЗ, СКЗ, Нолит.

Андрић 1991в: Иво Андрић, Знакови поред пута. Сабрана дела. Сарајево, Загреб, Београд, Љубљана, Скопје, Титоград: Свјетлост, Младост, Просвета, Државна заложба Словеније, Мисла, Побједа.

Андрић 1991г: Иво Андрић, Стазе, лииа, предели. Сабрана дела. Београд: Просвета, БИГЗ, СКЗ, Нолит.

Андрић 1991д: Иво Андрић, На Дрини ћуприја. Сабрана дела. Београд: Просвета, БИГЗ, СКЗ, Нолит.

Бошковић 2010: Драган Бошковић, Заблуде модернизма, Београд: Службени гласник. 
Бошковић 2011a: Dragan Bošković, Imperijalni okviri i geneza Andrićevog diskursa: odustajanje od identiteta, Die K. u. k. Periode in Leben und Schaffen von Ivo Andrić - Austrougarski period u životu i djelu Ive Andrića: (1892-1922), Beograd, Graz: Beogradska knjiga, Institut fur Slawistik der Karl FranzensUniveristat, 109-116.

Бошковић 2011б: Драган Бошковић, Бити Ћамил или не бити: Онтолошко заснивање идентитета у прози Иве Андрића, Иво Андрић у српској и европској књижевности, Београд: Филолошки факултет, МСЦ, 42-43.

Вучковић 1974: Радован Вучковић, Велика синтеза, Сарајево: Светлост.

Дерида 1988: Žak Derida, Struktura, znak i igra u diskursu humanističkih nauka, Strukturalistička kontroverza. Beograd: Prosveta, 298-315.

Дерида 2005: Žak Derida, Fragmenti, Glas i pismo: Žak Derida u odjecima, Beograd: Institut za filozofiju i društvenu teoriju, 13-28.

Јерков 1999: Александар Јерков, Неизрецива мисао смрти и неименљиво у Проклетој авлији, Свеске задужбине Иве Андрића, 15/12, 195-213.

Кољевић 1996: Светозар Кољевић, Андрићево виђење зла, Свеске задужбине Иве Андрића, 15/12, 227-237.

Лакан 1988: Žak Lakan, O strukturi kao inmikstovanju drugosti, što je postavka svakog subjekta, Strukturalistička kontroverza, Beograd: Prosveta, 218-231.

Тодорова 2006: Marija Todorova, Imaginarni Balkan, Beograd: XX vek.

Фуко 2007: Мишел Фуко, Поредак дискурса (приступно предаване на Колеж де Франсу, одржано 2. децембра 1970), Лозница: Карпос.

Џаџић 1991: Петар Џаџић, Легенда, прича, мит, историја, Иво Андрић, На Дрини ћуприја. Сабрана дела, Београд: Просвета, БИГЗ, СКЗ, Нолит, 7-102. 
Dragan B. Bošković

\section{THE NIHILISTIC FATE OF SIGN IN IVO ANDRIĆ'S FICTION}

By nihilating the conventional humanistic reading code, the paper suggests that what prevails in Ivo Andrićs opus is the thanatophilic identity of sign (grave, bridge, stone...), hence, its mainstream ideologically centered semantics must be re-examined in terms of ontological identity. Contrary to the interpretation of sign as an aesthetic (linguistic, narrative) or etno-culturological and geo-historical ideologeme, we aim to offer an interpretation of sign as the unbridgeable, as metacommunicativeness, as an ontological crack and semiological abyss. The crack in sign corresponds to the crack in subject, to the crack in the being, through which death/ Other is proclaimed as a the origin of signification, narration, and cultural identity.

Key words: sign, bridge, death, discourse, crack, Other 